\title{
Effect of Market Orientation on Organizational Performance (A Study of the Nigerian Banking Industry)
}

\author{
EGBERI, Agbarha Kelvin PhD \\ Department of Business Administration and Management \\ Delta State Polytechnic \\ Ozoro \\ OSIO, Ediri Joyce \\ Department of Business Administration and Management \\ Delta State Polytechnic \\ Ozoro
}

\begin{abstract}
This study examined the relationship between market orientation culture and organization performance among banks in Nigeria. Two hundred and twenty copies of questionnaire were distributed to staff of nine banks. Cross sectional research design was adopted. The population of the study comprises of 500 staff of selected Banks, and a total of 220 staff was sampled. Data were collected and analyzed using 210 retrieved sets questionnaire. Correlation and multiple regression analysis was conducted. The study established that there is a significant positive relationship between market oriented culture (customer orientation, competitor orientation and inter-functional coordination) and their effect on organizational performance in the Nigerian banking sector.The study also developed an enhanced model that combines the resource-based view of the firm theory and the dynamic capability theory to explain the organizational culture and market orientation culture of bank institutions in Nigeria as key determinants of bank performance. It is recommended that banks should consider customer needs in developing their corporate strategy.
\end{abstract}

Keywords: Market Orientation Culture, Customer Orientation, Competitor Orientation, Inter-Functional Coordination.

\section{Introduction}

In recent times, corporate entities have shifted their focus from a product based approach to the accomplishment of customer-centric thinking as well as customer value creation as these are vital for accomplishing a positive business performance through in depth knowledge of Market orientation. Accordingly, a rising number of studies have focused on the concept of "market orientation" with the plan of accepting the impact of organizational or corporate culture on market orientation and organizational performance (O'Cass \& Viet. 2007; Ogbonna \& Ogwo, 2013; Li \& Justin, 2008;Morah, Wilson \& Tzempelikos 2015).Market orientation fundamentally establishes tenets of organizational behavior with respect to a firm's business constituencies (customers, competitors, internal functions), which unambiguously make an effect on organizational performance. In line with this reasoning, researchers have trailed comprehensively a perceptive of the linkage between market orientation and performance, examining a direct causal link (Jakada, Musa Gambo, 2014; Njeru and Kiberia, 2016; Jaiyeoba, 2011), and even the roles of market orientation's antecedents (Ogbonna \& Ogwo, 2013). Conventional marketing wisdom holds that Market Orientation (MO) leads to better firm performance.

In this association, a market- oriented firm shall involve the customer in designing the marketing mix in order to offer customer value. Traditionally, marketing as a reflection of organizational culture addresses the extent to which the customer's values and beliefs are embedded within the organization and in its marketing activities (Morgan, 2009). Conversely, the values and norms of the firm (that is, its culture) must also be customer driven. Although, various researchers such as Homburg and Pflesser (2009), Egeren and O'Connor, (2010) andlbok and Akaninyene, (2014) have examined the correlation amid market oriented culture and organizational performance or organizational culture as driver of market-oriented culture and organizational performance, most of these studies were carried out in advanced nations. The link between market oriented culture (customer orientation, competitor orientation and inter-functional coordination) and their impact on organizational performance has not been totally established in the Nigerian environment. To the best of the researcher's knowledge, none of these studies have scrutinizes the impact of organizational culture and market oriented culture on performance of financial institutions in Nigeria using variables such as: 
customer orientation culture, competitor orientation culture and inter-functional coordination culture as independent variables and organizational performance as dependent variable. This study is motivated by the need to comprehend the effect of marketing orientation culture and its effect on organizational performance.

\section{Statement of the Problem}

Quite a few studies have tested the relationship between market orientation and performance, empirical evidence show disparities in degree and course of the correlation among these variables. Some researchers conclude that market orientation has insignificant impact on performance (Jakada, Musa \& Gambo, 2014; Ibrahim \& Shariff, 2016; Njeru \& Kiberia, 2016; Jaiyeoba, 2011: Adrianus, 2008). Although, a positive association has been recognized in the extant literature between market orientation and firm performance has been found, questions about the strength of this connection still lingers.

Therefore, it is obvious that empirical evidence on the correlation among market orientation and performance is inconclusive. Although research in marketing and organizational performance has been increasingly popular in Nigeria and in the banking industry, the correlation between market oriented and the performance of banks in the context of Nigeria has not been adequately examined. Following the above discussion, it is imperative to undertake a study of the relationship between market orientation and performance in the context of Nigerian Banking sector economy.

\section{Research Questions}

The following research questions guided the conduct of the study:

i. To what extent does customer orientation culture affect organizational performance?

ii. To what extent does competitor orientation culture affect organizational performance?

iii. To what extent does inter-functional coordination culture affect organizational performance?

\section{Research Objectives}

The general objective of the study is to achieve an understanding of the effect of a market oriented culture on performance of Banks in the Nigerian banking industry. The specific objectives are to:

i. examine the effect of customer orientation culture on organizational performance.

ii. determine the effect of competitor orientation culture on organizational performance.

iii. assess the effect of inter-functional coordination culture on organizational performance.

\section{Statement of Hypotheses}

$\mathrm{HO}_{1}$ : There is no significant relationship between customer orientation culture and organizational performance of the selected banks in Asaba, Delta State.

$\mathrm{HO}_{2}$ : There is no significant relationship between competitor orientation culture and organizational performance of the selected banks in Asaba, Delta State.

$\mathrm{HO}_{3}$ : There is no significant relationship between inter-functional coordination culture and organizational performance of the selected banks in Asaba, Delta State.

\section{Review of Related Literature}

\section{The Concept of Market Orientation}

Different conceptualizations of the market orientation (MO) concept have been proposed in the academic and professional literature. The key contributions are those of Kohli and Jaworski (1990), Narver and Slater (1990), Brownhilder, (2016) and Deshpandé and Farley (1998). Market orientation has been recognized as major success factors (KSFs) in practically every organizations of present day. There are two well-known concepts of market orientation that were given by Jaworski and Kohli (1990) and Narver and Slater (1990). While Jaworski and Kohli (1990) measured market orientation as the realization of the marketing concept, Narver and Slater (1990) considered it as an organizational culture. According to Upadhay and Baber (2013) in Njeru and Kiberia(2016) emphasized that in present era, academicians, researchers and practitioners have increased their focus on market orientation and the factors that produce this orientation in the organizations.

According to (Jaiyeoba, 2011), if the similarity with the Kohli and Jaworski (1990) model is substantial, the Narver and Slater model is not only more detailed but also theoretically more preventive, because it is limited to two market players: customers and competitors. Jaiyeoba (2011) assume the following definition: Market orientation is a business corporate culture, disseminated in the organization through inter-functional coordination, having the objective to design and promote, at a profit for the firm, greater value solutions to the firm's direct and indirect customers and to the other involved market stakeholders (Ibok \& Akaninyene, 2014). 


\section{Market Orientation Culture}

Market orientation as an organizational culture is a corporate business philosophy that puts the customer's satisfaction first, taking into account the role played by the other market actors. In other words, a market orientation culture can be termed as a "subculture" within the overarching organizational or corporate culture (Shehu\& Mahmood, (2014). There have been many studies indicating how a market orientated culture can be implemented (Shaw, 2010; Harrower, 2011; Hooley et al, 2008; Kotler et al, 2005) as cited in Piercy, Harris\&Lane (2017).

\section{Organizational Culture, Market Orientation and Performance}

At first view, there might materialize to be overlie among organizational culture and market orientation constructs (Pinho, Rodrigues \& Dibb, 2013). The direct correlation among market orientation and performance has been studied over a long period of time. Preceding studies provide ambivalent results on the correlation amid market orientation and performance. A positive correlation among market orientation and organizational performance has been recognized (Zayed\& Alawad, 2017).

More recently, Njeru (2013) recognized a positive correlation between market orientation and performance of expedition operators in Kenya. Other researchers have reported irrelevant relationship among market orientation and performance (Agarwal, Erramili, \& Dev, 2003;Olanipekun, Aje\& Abiola-Falemu, (2013). The existence of such oblique results reinforces the need for more studies on the connection amid market orientation and performance. Previous studies indicate the continuation of a positive correlation between organizational culture and market orientation (Njeru, 2013). Even though researchers argue that organizational culture supports implementation of market orientation, there is slight empirical evidence to support this claim. Whereas numerous researchers have dedicated more thoughtfulness to elucidate the nature of culture, lesser articles have been contributed on the associations among organizational culture, market orientation and performance in an incorporated manner.

Several studies have tested the direct impact of market orientation on performance (Sandvik \& Sandvik, 2003; Cano et al., 2004; Kirca et al., 2005; Shoham et al., 2005; Grinstein, 2008; Zebal \& Goodwin, 2012; Njeru, 2013) as cited in Zayed\& Alawad (2017). Nevertheless, the influencing role of organizational culture on market orientation and performance has not been empirically tested.

\section{Organization Culture, Market Oriented Culture, Innovativeness and Performance}

A key subject for numerous companies is the improvement and continuation of an entrepreneurial spirit within the organization, defining new business opportunities and enhancing the capability of the firm to react to the changing competitive environment. A specific challenge is to understand what organizations can do to and promote organization beliefs, principles, and prospects (cultures) that are positive encouragement to innovation and change.

\section{Dynamic Capabilities Theory}

The theory of dynamic capability was first advanced by Teece, Pisano and Shuen, in their 1997 paper Dynamic Capabilities and Strategic Management, and it was defined as "the firm's capability to incorporate, build, and reconfigure internal and external proficiencies to address swiftly changing environments." The dynamic capabilities theory addresses the weaknesses of the resource based theory. It argues that performance is explained by organizational capabilities for obtaining, hoarding and deploying resources in ways that replicate changing market conditions (Makadok, 2001; Teece, Pisano and Sheun, 1997). Capabilities are complex, structured and multi-dimensional. Marketing competences are developed through unremitting application of marketing knowledge and skills infatuated by employees to solving marketing problems (Vorhies, Harker, \& Rao, 1999).

The theory explains "the firm's capacity to incorporate, build, and re-configure internal and external proficiencies to address swiftly changing surroundings" (Teece, Pisano and Shuen, 1997). Dynamic capability focuses on investigating how to build competitive advantages in extremely competitive surroundings. If an enterprise could learn from customers, superior to competitors, to change its core business processes and practices, continuing modernization, improvement and allocation of resources, it will create customer value superior to competitors, lastly gaining exceptional performance in the market (Maklan et al, 2009). By means of dynamic capabilities, enterprise could respond rapidly to market change.

\section{Empirical Studies}

Piercy, Harris andLane (2017) empirically examine strategic orientations, marketing capabilities and firm performance in the framework of front managers in service organizations. This work widens and empirically tests a model that associations option strategic orientations with organization performance, through the arbitrating impact of marketing capabilities. The effect of environmental forces and organizational distinctiveness on the assessment to trail beneficial strategic orientations is also examined. 
Using data collected from 316 bank branch managers, the authors locate that market instability, strength of competition, and transference in decision making play a fundamental role in determining managerial strategic priorities. Furthermore, competitor orientation and innovation orientation put in considerably to the development of marketing capabilities. In turn, marketing capabilities have a positive effect on firm performance. The researchers converse the managerial insinuations of study findings and propose directions for future research.

Apiah-Adu (2011) empirically tested market orientation and performance in a transition economy (Ghana). The researcher argues that although the management literature is stuffed with empirical studies on market orientation, a assessment of the proof so far advocates that the mass of studies have been based on industrialized countries. The author argues further that regardless of the reality that the business surroundings in numerous developing economies are swiftly undergoing transformation, thereby influencing the metamorphoses of organizations from fabrication to promotion orientation, empirical research involving to market orientation in rising countries remains negligible. In an effort to present further approaching into the global significance of market orientation, this study scrutinized its connection with business performance in an opened developing country. Probable influences of market enthusiasm, competitive strength and market growth on this connection were also examined. The results designate that even though market orientation does not emerge to have a through effect on sales growth or return on investment, the competitive surroundings does control the market orientation-performance linkage.

Amue and Igwe (2013) examine the effect of internal marketing on market orientation and business performance. The idea of this paper is to scrutinize the effect of internal marketing on commercial banks' organization obligation, market orientation, and business performance. Data collection from 12 commercial banks of Pakistan was embattled. Quantitative approaches were used for data collection from 500 bank employees and effective data was supplementary investigated by using inferential techniques on SPSS 18.00. The findings of the study recommended that internal marketing programs had a momentous effect on employees' commitment, their market orientation and overall profitability of the organization. In accumulation, the mediating connection of organization commitment with internal marketing and market orientation was not supported. The studies investigate the involvements by incorporating element of business performance and market orientation in a particular study. From the study, the authors suggest that parsimonious aspect is followed by taking the only mediating variable i.e. organization commitment. Lastly, this study is one of few papers that focus on internal marketing in Pakistani banking industry.

Accordingly, Aliyu (2014) empirically examined the effect of organizational culture and market orientation on performance of microfinance institutions in Kenya. The aim of their study is to evaluate the impact of organizational culture and market orientation on performance. The population of the study comprises microfinance institutions that are members of the Association of Microfinance Institutions (AMFI) in Kenya. The researchers used descriptive crosssectional survey design and collected primary data using structured questionnaire. Their hypotheses were through regression analysis. Their results reveal that organizational culture extensively and positively affect variations in performance. The fractional conciliation impact of market orientation on the correlation linking organizational culture and performance was established.

The researchers recommended that the admiring impact of organizational culture on market orientation entails that organizations need to spend further resources in cultivation market orientation to create sustainable competitive advantage in the course of delivery of advanced customer experience. They concluded that the effect of organizational culture and market orientation on performance is more plausible for mature industries regarded as diverse in terms of customer needs.

\section{Methods}

According to Agbonifoh and Yomere (1999), survey research method is the systematic gathering of information from respondents for the purpose of understanding and/or predicting some aspect of the behavior of the population interest. This method was chosen because it assisted the researcher in getting the required data and also in answering the research questions in order to achieve the research objectives. The population of this study consists of senior, middle and lower management staffs of the selected nine (9) banks in Asaba metropolis, Delta State. These banks share a common market orientation culture and are homogenous in nature and operation. Since it is not possible to study the entire population of banks in the banking sector due to finance and geographical constraints, the researcher chose nine (9) banks out of the nineteen (19) existing banks in the country as the sample for this study. For the purpose of this study, the research population comprised of lower, middle and the senior management cadres of employees of the selected banks, and is presented in the table below: Access Bank plc, Diamond Bank plc, EcoBank Transnational Inc, First City Monument Bank, First Bank, Guarantee Trust Bank, Zenith Bank and Polaris bank plc. 
The sample size appropriate for good representation of the population of the study was determined using the Taro Yamen's sample size formula, yielding 220 staff. The probability sampling method was employed in this study including the simple random technique.

TABLE 3.1 Proportion Sample Size from each Bank

\begin{tabular}{|l|l|l|}
\hline SN & \multicolumn{1}{|c|}{ Banks } & Number of Staff \\
\hline 1 & Access bank & $(55 / 500) \times 220=24$ \\
\hline 2 & Diamond bank & $(50 / 500) \times 220=22$ \\
\hline 3 & Eco bank & $(70 / 500) \times 220=31$ \\
\hline 4 & FCMB & $(57 / 500) \times 220=25$ \\
\hline 5 & Fidelity bank & $(45 / 500) \times 220=20$ \\
\hline 6 & First bank & $(64 / 500) \times 220=28$ \\
\hline 7 & GTB & $(57 / 500) \times 220=25$ \\
\hline 8 & Zenith Bank & $(47 / 500) \times 220=21$ \\
\hline 9 & Polaris bank & $(55 / 500) \times 220=24$ \\
\hline Total & & 220 \\
\hline
\end{tabular}

Source: Researcher's computation

The researcher used questionnaire method to gather information without manipulating the respondents for appropriateness. The researcher also used the Likert five-scale questionnaire model i.e. (Strongly agree, agree, disagree, strongly disagree and undecided). Face and content validity method were used in order to validate the research instrument for data collection. Sets of the structured questionnaire were given to some experts in the academics and the banking industry to carry out both face and content validity. This ensured that the questions are simple and easily understood by the respondents. Consequently, adjustments and corrections were effected to ensure that they elicit the desired information for the study.

Therefore, scale reliability for this study was calculated using Cronbach Alpha. Given the nature of response used to construct the scale, Cronbach Alpha Coefficient is considered as the most appropriate statistical tool to test for reliability coefficient. According to Bryman and Bell (2003), "An Alpha Coefficient of 0.80 is generally accepted as a good level of internal reliability of the instrument, though an Alpha level of 0.7 is also considered to be efficient". From table 3.2 below, the calculated CA is 0.894 and is higher than the recommended acceptable measure of CA 0.7 which makes measurement of the model reliability accepted.

Table 3.2 Reliability Statistics

\begin{tabular}{|l|l|l|}
\hline Cronbach's Alpha & Cronbach's Alpha Based on Standardized Items & N of Items \\
\hline .892 & .894 & 13 \\
\hline
\end{tabular}

The statistical techniques used for processing the data and testing the hypotheses for this study were correlation and regression analyses via the use of statistical package for social science (SPSS) software version 24.

\section{Results}

220 copies of questionnaires were administered to staffs of the nine banks selected and of this figure represent $95.45 \%$ of these 210 questionnaires were successfully retrieved showing respondent rate of $95.45 \% .87(41 \%)$ of the total respondents are male while $123(59 \%)$ are female; 80(38\%) of the respondents are below 30 years, $71(34 \%)$ are within 31-40 years and 59(28\%) are above 40 years of age. By marital status, 89(42\%) are single, 109 (52\%) are married, $9(4 \%)$ are divorced while $3(2 \%)$ are separated. Academically, $85(40 \%)$ of the total respondents are OND/NCE holders, 93(44\%) of the total respondents are HND/B.sc holders, 25(12\%) have M.sc/ MBA degrees while 7(4\%) have PhD degrees. Lastly, for working experience, 107(51\%) have worked 1-5 years, 71 (34\%) have worked 6-10 years while 32 $(15 \%)$ have worked above 10 years.

Research Question One: To what extent does customer orientation culture affect organizational performance in the Nigerian banking industry? 
Table 4.2: Showing Customer Orientation Culture Question from number 7-10

\begin{tabular}{|c|c|c|c|c|c|c|}
\hline $\mathrm{S} / \mathrm{N}$ & Customer Orientation Culture & $\begin{array}{l}\text { SA } \\
5\end{array}$ & $\begin{array}{l}\text { A } \\
4\end{array}$ & $\begin{array}{l}\mathrm{U} \\
3\end{array}$ & $\begin{array}{l}\mathrm{D} \\
2\end{array}$ & $\begin{array}{l}\text { SD } \\
1\end{array}$ \\
\hline 1 & $\begin{array}{l}\text { Our business objectives are driven } \\
\text { primarily by customer satisfaction. }\end{array}$ & $\begin{array}{l}68 \\
(32 \%)\end{array}$ & $\begin{array}{l}86 \\
(41 \%)\end{array}$ & $\begin{array}{l}2 \\
(1 \%)\end{array}$ & $\begin{array}{l}24 \\
(11 \%)\end{array}$ & $\begin{array}{l}30 \\
(15 \%)\end{array}$ \\
\hline 2 & $\begin{array}{l}\text { We constantly monitor our level of } \\
\text { commitment and orientation to } \\
\text { serving customers' needs. }\end{array}$ & $\begin{array}{l}73 \\
(35 \%)\end{array}$ & $\begin{array}{l}67 \\
(32 \%)\end{array}$ & $\begin{array}{l}5 \\
(2 \%)\end{array}$ & $\begin{array}{l}31 \\
(15 \%)\end{array}$ & $\begin{array}{l}34 \\
(16 \%)\end{array}$ \\
\hline 3 & $\begin{array}{l}\text { Our strategy for competitive } \\
\text { advantage is based on our } \\
\text { understanding of customers' needs. }\end{array}$ & $\begin{array}{l}61 \\
(29 \%)\end{array}$ & $\begin{array}{l}73 \\
(35 \%)\end{array}$ & $\begin{array}{l}7 \\
(3 \%)\end{array}$ & $\begin{array}{l}38 \\
(18 \%)\end{array}$ & $\begin{array}{l}31 \\
(15 \%)\end{array}$ \\
\hline
\end{tabular}

Source: Field survey (2019)

From table $4.2,68(32 \%)$ of the total respondents strongly agreed that "Our business objectives are driven primarily by customer satisfaction", 86(416\%) agreed. 2(1\%) is undecided while 24(11\%) disagreed and 30(15\%) strongly disagreed to the first question. For the second question, 73(35\%) of the total respondents strongly agreed that "We constantly monitor our level of commitment and orientation to serving customers' needs", 67(32\%) agreed. 5(2\%) is undecided while 31(15\%) disagreed and 34(16\%) strongly disagreed. For the third question, 61(29\%) of the total respondents strongly agreed that "Our strategy for competitive advantage is based on our understanding of customers' needs." 73(35\%) agreed. 7(3\%) are undecided while 38(18\%) disagreed and 31(15\%) strongly disagreed.

Research Question Two: To what extent does competitor orientation culture affect organizational performance in the Nigerian banking industry?

Table 4. 3: Showing Competitor orientation culture

\begin{tabular}{|c|c|c|c|c|c|c|}
\hline $\mathrm{S} / \mathrm{N}$ & $\begin{array}{ll}\text { COMPETITOR } & \text { ORIENTATION } \\
\text { CULTURE } & \end{array}$ & $\begin{array}{l}\text { SA } \\
5\end{array}$ & $\begin{array}{l}\mathrm{A} \\
4\end{array}$ & $\begin{array}{l}\text { U } \\
3\end{array}$ & $\begin{array}{l}\mathrm{D} \\
2\end{array}$ & $\begin{array}{l}\text { SD } \\
1\end{array}$ \\
\hline 1 & $\begin{array}{l}\text { Our salespeople regularly share } \\
\text { information within our business } \\
\text { concerning competitors' strategies. }\end{array}$ & $\begin{array}{l}48 \\
(23 \%)\end{array}$ & $\begin{array}{l}91 \\
(43 \%)\end{array}$ & $\begin{array}{l}6 \\
(3 \%)\end{array}$ & $\begin{array}{l}24 \\
(11 \%)\end{array}$ & $\begin{array}{l}41 \\
(20 \%)\end{array}$ \\
\hline 2 & $\begin{array}{l}\text { We rapidly respond to competitive } \\
\text { actions that threaten us }\end{array}$ & $\begin{array}{l}53 \\
(25 \%)\end{array}$ & $\begin{array}{l}81 \\
(39 \%)\end{array}$ & $\begin{array}{l}7 \\
(3 \%)\end{array}$ & $\begin{array}{l}31 \\
(15 \%)\end{array}$ & $\begin{array}{l}38 \\
(18 \%)\end{array}$ \\
\hline 3 & $\begin{array}{l}\text { Top management regularly discusses } \\
\text { competitors' strengths and strategies. }\end{array}$ & $\begin{array}{l}66 \\
(31)\end{array}$ & $\begin{array}{l}73 \\
(35 \%)\end{array}$ & $\begin{array}{ll}12 \\
(6 \%)\end{array}$ & $\begin{array}{l}34 \\
(16 \%)\end{array}$ & $\begin{array}{l}25 \\
(12 \%)\end{array}$ \\
\hline
\end{tabular}

Source: Field survey (2019)

From table 4.3 above, $48(23 \%)$ of the total respondents strongly agreed that "Our salespeople regularly share information within our business concerning competitors' strategies", 91(43\%) agreed. 6(3\%) is undecided while $24(11 \%)$ disagreed and $41(20 \%)$ strongly disagreed to the first question. For the second question, 53(25\%) of the total respondents strongly agreed that "We rapidly respond to competitive actions that threaten us", $81(39 \%)$ agreed. $7(3 \%)$ is undecided while 31(15\%) disagreed and 38(18\%) strongly disagreed. For the third question, 66(31\%) of the total respondents strongly agreed that "Top management regularly discusses competitors' strengths and strategies" $73(35 \%)$ agreed. $12(6 \%)$ are undecided while 34(16\%) disagreed and 25(12\%) strongly disagreed.

Research Question Three: To what extent does inter-functional coordination culture affect organizational performance in the Nigerian banking industry?

Table 4.4: Showing Inter-functional coordination culture Question from number 18-23

\begin{tabular}{|c|c|c|c|c|c|c|}
\hline $\mathrm{S} / \mathrm{N}$ & $\begin{array}{ll}\text { INTER-FUNCTIONAL } & \text { COORDINATION } \\
\text { CULTURE } & \end{array}$ & $\begin{array}{l}\text { SA } \\
5\end{array}$ & $\begin{array}{l}\text { A } \\
4\end{array}$ & $\begin{array}{l}\mathrm{U} \\
3\end{array}$ & $\begin{array}{l}\mathrm{D} \\
2\end{array}$ & $\begin{array}{l}\text { SD } \\
1\end{array}$ \\
\hline 1 & $\begin{array}{l}\text { We freely communicate information about our } \\
\text { successful customer experiences across all } \\
\text { business factors. }\end{array}$ & $\begin{array}{l}68 \\
(32 \%)\end{array}$ & $\begin{array}{l}61 \\
(29 \%)\end{array}$ & $\begin{array}{ll}5 \\
(2 \%)\end{array}$ & $\begin{array}{l}29 \\
(14 \%)\end{array}$ & $\begin{array}{l}47 \\
(22 \%)\end{array}$ \\
\hline 2 & $\begin{array}{l}\text { All of our business functions are integrated in } \\
\text { serving the needs of our target markets. }\end{array}$ & $\begin{array}{l}53 \\
(25 \%)\end{array}$ & $\begin{array}{l}81 \\
(39 \%)\end{array}$ & $\begin{array}{l}9 \\
(4 \%)\end{array}$ & $\begin{array}{l}31 \\
(15 \%)\end{array}$ & $\begin{array}{l}36 \\
(17 \%)\end{array}$ \\
\hline 3 & $\begin{array}{l}\text { All of our managers understand how everyone } \\
\text { in our business can contribute to creating } \\
\text { customer value. }\end{array}$ & $\begin{array}{l}68 \\
(32 \%)\end{array}$ & $\begin{array}{l}73 \\
(35 \%)\end{array}$ & $\begin{array}{ll}2 \\
(1 \%)\end{array}$ & $\begin{array}{l}42 \\
(20 \%)\end{array}$ & $\begin{array}{l}25 \\
(12 \%)\end{array}$ \\
\hline
\end{tabular}

Source: Field survey (2019) 
From table 4.4 above, 68(32\%) of the total respondents strongly agreed that "We freely communicate information about our successful customer experiences across all business factors", 61(29\%) agreed. 5(2\%) is undecided while $29(14 \%)$ disagreed and $47(22 \%)$ strongly disagreed to the first question. For the second question, 53(25\%) of the total respondents strongly agreed that "All of our business functions are integrated in serving the needs of our target markets", 81(39\%) agreed. 9(4\%) is undecided while 31(15\%) disagreed and 36(17\%) strongly disagreed.

For the third question, $68(25 \%)$ of the total respondents strongly agreed that "All of our managers understand how everyone in our business can contribute to creating customer value" $73(35 \%)$ agreed. $2(1 \%)$ are undecided while $42(20 \%)$ disagreed and 25(12\%) strongly disagreed.

Table 4.6 Showing Organizational Performance

\begin{tabular}{|c|c|c|c|c|c|c|}
\hline $\mathrm{S} / \mathrm{N}$ & Organizational performance & $\begin{array}{l}\text { SA } \\
5\end{array}$ & $\begin{array}{l}\mathrm{A} \\
4\end{array}$ & $\begin{array}{l}\mathrm{U} \\
3\end{array}$ & $\begin{array}{l}\mathrm{D} \\
2\end{array}$ & $\begin{array}{l}\text { SD } \\
1\end{array}$ \\
\hline 1 & $\begin{array}{l}\text { Authority is delegated so that employees can at their } \\
\text { own time perform specific duties assigned to them. }\end{array}$ & $\begin{array}{l}48 \\
(23 \%)\end{array}$ & $\begin{array}{l}85 \\
(40 \%)\end{array}$ & $\begin{array}{ll}4 \\
(2 \%)\end{array}$ & $\begin{array}{l}44 \\
(21 \%)\end{array}$ & $\begin{array}{l}29 \\
(14 \%)\end{array}$ \\
\hline 2 & The leaders and managers "practice what they preach" & $\begin{array}{l}58 \\
(28 \%) \\
\end{array}$ & $\begin{array}{l}64 \\
(31 \%)\end{array}$ & $\begin{array}{l}5 \\
(2 \%) \\
\end{array}$ & $\begin{array}{l}47 \\
(22 \%)\end{array}$ & $\begin{array}{l}36 \\
(17 \%) \\
\end{array}$ \\
\hline 3 & $\begin{array}{l}\text { There is a clear and consistent set of values that } \\
\text { governs the way we do business. }\end{array}$ & $\begin{array}{l}49 \\
(23 \%)\end{array}$ & $\begin{array}{l}68 \\
(32 \%)\end{array}$ & $\begin{array}{l}7 \\
(3 \%)\end{array}$ & $\begin{array}{l}39 \\
(19 \%)\end{array}$ & $\begin{array}{l}47 \\
(22 \%)\end{array}$ \\
\hline 4 & $\begin{array}{l}\text { When disagreements occur, we work hard to achieve } \\
\text { "win-win" solutions. }\end{array}$ & $\begin{array}{l}50 \\
(24 \%)\end{array}$ & $\begin{array}{l}70 \\
(33 \%)\end{array}$ & $\begin{array}{ll}5 \\
(2 \%)\end{array}$ & $\begin{array}{l}49 \\
(23 \%)\end{array}$ & $\begin{array}{l}36 \\
(17 \%)\end{array}$ \\
\hline
\end{tabular}

Source: Field survey (2019)

From table 4.6 above, $48(21 \%)$ of the total respondents strongly agreed that "Authority is delegated so that employees can at their own time perform specific duties assigned to them" 85(40\%) agreed. 4(2\%) is undecided while $44(21 \%)$ disagreed and 29(14\%) strongly disagreed to the first question. For the second question, 58(28\%) of the total respondents strongly agreed that "The leaders and managers "practice what they preach", 64(31\%) agreed. 5(2\%) is undecided while $47(22 \%)$ disagreed and 36(17\%) strongly disagreed. For the third question, 49(23\%) of the total respondents strongly agreed that "There is a clear and consistent set of values that governs the way we do business", 68(32\%) agreed. 7(3\%) are undecided while 39(19\%) disagreed and 47(22\%) strongly disagreed. For the fourth question, 50(24\%) of the total respondents strongly agreed that "When disagreements occur, we work hard to achieve "win-win" solutions", 70(33\%) agreed. 5(2\%) are undecided while 49(23\%) disagreed and 36(17\%) strongly disagreed. Generally, the model summary table of the research is as given below:

\section{Test of Hypotheses}

The hypotheses formulated are tested below using the results obtained from the regression analysis.

Decision Rule: Reject null hypothesis (H0) if p-value is less than $0.05(5 \%)$ and if not, accept the alternate hypothesis. This result is seen below:

\begin{tabular}{|c|c|c|c|c|c|c|}
\hline \multicolumn{6}{|c|}{$\begin{array}{c}\text { Table 4.7 Regression Analysis Coefficient for Market Orientation Culture and Organizational } \\
\text { performance }\end{array}$} & \multirow{3}{*}{ Sig. } \\
\hline \multirow{2}{*}{\multicolumn{2}{|c|}{ Model }} & \multicolumn{2}{|c|}{$\begin{array}{l}\text { Unstandardized } \\
\text { Coefficients }\end{array}$} & \multirow{2}{*}{$\begin{array}{c}\text { Standardized Coefficients } \\
\text { Beta } \\
\end{array}$} & \multirow[t]{2}{*}{$\mathrm{T}$} & \\
\hline & & $\mathrm{B}$ & Std. Error & & & \\
\hline \multirow[t]{6}{*}{1} & (Constant) & 2.795 & 1.866 & & 2.011 & .0011 \\
\hline & Customer & .568 & .272 & .892 & 1.498 & .042 \\
\hline & Orientation & .512 & 613 & .877 & 1.899 & .019 \\
\hline & Competitor & .909 & .799 & .741 & 2.300 & .042 \\
\hline & Orientation & & & & & \\
\hline & $\begin{array}{l}\text { Inter-functional } \\
\text { Co-ord. }\end{array}$ & & & & & \\
\hline \multicolumn{7}{|c|}{ a. Dependent Variable: Organizational Performance } \\
\hline
\end{tabular}

Source: SPSS Version 24

\begin{tabular}{|l|l|l|l|l|}
\hline Model & R & R Square & Adjusted R Square & Std. Error of the Estimate \\
\hline 1 & .772 & .596 & .591 & 2.169 \\
\hline
\end{tabular}

Source: SPSS Version 24 
Table 4.7 reveals the extent to which Customer Orientation culture, Competitor Orientation culture, Inter-functional Coordination culture and Innovative Market Orientation culture accounted for change in Organizational performance as seen by the adjusted R square, which shows $78.7 \%(0.787)$ of change in Organizational performance is brought about by Customer Orientation culture, Competitor Orientation culture, Inter-functional Coordination culture and Innovative Market Orientation culture.

\section{Test of Hypothesis One}

$\mathbf{H O}_{1}$ : There is no significant relationship between Customer Orientation Culture and Organizational Performance of the selected banks in Asaba, Delta State.

From table 4.7 the sig. value is 0.042 . This value is less than the set value of 0.05 used as level of significance. Thus, the study rejects the null hypothesis $\left(\mathrm{H}_{0}\right)$ and accept the alternate hypothesis $\left(\mathrm{H}_{1}\right)$ which states that there is significant relationship between Customer Orientation Culture and Organizational Performance of the selected banks.

\section{Test of Hypothesis Two}

$\mathbf{H O}_{2}$ : There is no significant relationship between Competitor Orientation Culture and Organizational Performance of the selected banks in Asaba, Delta State.

The significant value is 0.019 . This value is less than the set value of 0.05 used as level of significance. Thus, the study rejects the null hypothesis $\left(\mathrm{H}_{0}\right)$ and accept the alternate hypothesis $\left(\mathrm{H}_{1}\right)$ which states that there is significant relationship between Competitor Orientation Culture and Organizational Performance of the selected banks.

\section{Test of Hypothesis Three}

\section{$\mathrm{HO}_{3}$ : There is no significant relationship between inter-functional coordination culture and organizational performance of the selected banks in Asaba, Delta State.}

The significant value is 0.042 . less than the set value of 0.05 used as level of significance. Thus, the study rejects the null hypothesis $\left(\mathrm{H}_{0}\right)$ and accepted the alternate hypothesis which states that there is significant relationship between inter-functional coordination culture and organizational performance of the selected banks.

The adjusted $r$ square value on the overall,is 0.591 (emphasizing non-spuriousity of variable) and this shows that 59\% of the dependent variable is explained by the independent variable.

\section{Discussion of Findings}

Customer Orientation is significantly positively related with organizational performance. The $t$ statistics values is 1.498. It implies that Customer Orientation culture has a positive trend with organizational performance. One percent $(1 \%)$ movement in organizational performance is accounted by standardized coefficient of $(\beta=0.892)$.

This is in line with the finding of Brownhilder (2016) who discovered a positive relationship between customer orientation culture and organizational performance $(\beta=0.894, \mathrm{t}=1.410, \mathrm{P}=0.019)$. Accordingly, Murtala amd Mohd (2016) also showed in its findings, a positive relationship between customer orientation culture and organizational performance $(\beta=0.677, \mathrm{t}=2.390, \mathrm{P}=0.032$. by sharp contrast, Balarabe and Musa (2014) and Aliyu and Mahmood (2014) discovered a negative relationship between customer orientation and organizational performance with $(\beta=$ 0.0094, $\mathrm{t}=0.110, \mathrm{P}=0.926)$ and $(\beta=0.424, \mathrm{t}=0.391, \mathrm{P}=0.695)$.

Competitor orientation has a significant positive relationship with organizational performance. The $t$ statistics values on the other hand show 1.899. It implies that competitor orientation culture has a positive trend with organizational performance. One percent $(1 \%)$ movement in organizational performance is accounted by standardized coefficient of $(\beta=0.877)$.

This is in line with the finding of Ibok and Eno (2014) who discovered a positive relationship between competitor orientation culture and organizational performance $(\beta=0.687, \mathrm{t}=2.920, \mathrm{P}=0.021)$, Olanipekun and Abiola-Falemu (2013) also showed in their findings, a positive relationship between competitor orientation culture and organizational performance $(\beta=0.591, \mathrm{t}=1.139, \mathrm{P}=0.019)$; similarly, Adrianus (2008), Ogbonna and Ogwo (2013) and Jaiyeoba (2011) also discovered a positive relationship between competitor orientation and organizational performance with $(\beta=$ $0.814, \mathrm{t}=3.540, \mathrm{P}=0.0499),(\beta=0.699, \mathrm{t}=1.971, \mathrm{P}=0.002)$ and $(\beta=2.124, \mathrm{t}=1.299, \mathrm{P}=0.05)$ respectively.

The significance value forInter-functional coordination culture is 0.042 from the coefficient table. The $t$ statistics values on the other hand show 2.300. It implies that Inter-functional coordination culture has a positive trend with organizational performance. One percent $(1 \%)$ movement in organizational performance is accounted by standardized coefficient of $(\beta=0.741)$. 
This is in consonant with the finding of Njeru and Kiberu (2016) who discovered a positive relationship between interfunctional coordination culture and organizational performance $(\beta=0.712, t=1.542, \mathrm{P}=0.029)$, Olanipekun and Abiola-Falemu (2013) also showed in their findings, a positive relationship between inter-functional coordination culture and organizational performance $(\beta=0.883, \mathrm{t}=2.469, \mathrm{P}=0.0079)$. Similarly, Goboul (2015) and Gonewe and Sunny (2013) discovered a positive relationship between inter-functional coordination and organizational performance with $(\beta=0.923, \mathrm{t}=2.307, \mathrm{P}=0.0036),(\beta=0.677)$ and $(\beta=0.519, \mathrm{t}=0.781, \mathrm{P}=0.012)$ respectively. On a contrary note, Morah, Wilson and Tzempelikos (2016) discovered a negative relationship between inter-functional coordination and organizational performance with $(\beta=0.387, \mathrm{t}=-0.711, \mathrm{P}=0.18599)$.

\section{Conclusions}

The current research has extended the literature of market orientation and performance nexus in several ways. First, the result of this research suggest that customer orientation and competitor orientation are a positive and significant predictor of organizational performance. This study identified those banks in Nigerian banking industry with competitor orientation and customer orientation as their marketing strategy to accomplish better performance. Furthermore, this study found that customer orientation influences the performance to some extent higher than the competitor orientation. As a final point, the study provided empirical confirmation on the practices and effects of market orientation toward organizational performance of banks in Nigeria, which has been given very less consideration in the marketing literature so far. Marketing orientation is understood as efficient generation of information, disseminations of information and responsiveness to gained information. These three activities are mainly related with the information about customer, competition and market.

Based on the results of research, managers should focus on the stated fields. The essence of implementing this concept into practice of the companies is to set the customer into the center of company's attention and ensure satisfaction of its customers. Obtaining of information is also interrelated with the competition, whereas company should observe their marketing activities, strategies and offered products. Within the marketing orientation enterprise should acquire and collect information about the market in which it operates. Company should observe new trends in their business surroundings and should support their effects on customer. Responding to new market trends companies can increase the competitive advantage over the competitors. Essential information about customers, competition and new market trends is indispensable to dispense around all departments of a company, e.g. throughout the meetings. During these meeting employees can analyze obtained information and negotiate the ways in which the company will respond to the information provided. The study contributed to knowledge thus:

1. The study has also contributed knowledge to the existing literature on how organizational culture and market oriented culture affect the performance of financial institutions in Nigeria using variables such as: customer orientation culture, competitor orientation culture and inter-functional coordination.

2. The study provides empirical envidence on the practices and effects of market orientation culture on organizational performance of banks in Nigeria.

\section{Recomendaciones}

The following recommendations are offered to improve business performance:

i. Senior managers of the company allocated regular meetings to discuss their competitors.

ii. To provide information about competitors to other departments.

iii. Personnel, units and other resources coordinate such a way to create value for customers as coordinated and integrated together

\section{References}

Adrianus S, P (2008) Effects of Market Orientation on Business Performance: Empirical Evidence from Iceland. Journal of Marketing and International Business, 23(1); 1-21

Agarwal, Sanjeev, Krishna M. Erramilli, and Chekitan D. Dev(2003), "Market Orientation and Antecedents and Consequences of Market and Innovation Orientations. Journal of Business Antecedents to new product success. Journal of Marketing Research, 34(1): 107-16.

Aliyu M. S (2014), An Empirical Analysis of Market Orientation and Business Performance Relationship in the Context of Developing Economy. International Journal of Academic Research in Business and Social Sciences, 4(9); 457-470 
Aliyu M. S and Mahmood, R (2014), The Relationship between Market Orientation and Business Performance of Nigerian SMEs: The Role of Organizational Culture. International Journal of Business and Social Science, 5 (9); 159-168

Amue, G. J and Igwe, R. S (2013) Market Orientation, Firms' Level Characteristics and Environmental Factors: Investigating the Moderating Effects on E-Commerce Competence. IOSR Journal of Business and Management, 12(4): 1-8

Appia-Adu K (1999), Marketing Effectiveness and Customer Retention in the Service Sector. Service Industries Journal, 19 (3), 26-41.

Brownhilder, N. N (2016) Market orientation and performance: The contingency role of external Environment. Environmental Economics (open-access), 7(2): 7-14

Deshpande, R and Farle, John U.(2004), Organizational culture, market orientation, innovativeness, and firm performance: an international research odyssey.International Journal of Research in Marketing, 21(1), 3-22

Deshpande, R and Webster, F.E. (1989), Organizational Culture and Marketing: Defining the Research Agenda. Journal of Marketing, 53(1): 3-15

Egeren, M.V. and S. O'Connor (2010), Drivers of Market Orientation and Performance in Service Firms, Journal of Service Marketing, 12 (1), 39-58.

Homburg, C and Pflesser, P. (2009) A Multiple-Layer Model of Market-Oriented Organizational Culture: Measurement Issues and Performance Outcomes. Journal of Marketing Research, 37(4): 449-462.

Ibok, N. I and Akaninyene, E. N (2014) Market Orientation and Organizational Performance: The case of MicroFinance Banks. International Journal of Economic and Business Review, 2(12): 25-33,

Jaiyeoba, O (2011) The Impact of Market Orientation on SMMEs in Developing Economies: A Case-study of Botswana. International Journal of Business Administration, 2(3): 132-139

Jakada, B. A and Gambo, M. K.K. (2014), A Conceptual Analysis of Market Orientation Philosophy in the Hospitality Industry of Nigeria. Journal of Marketing and Management, 5 (1): 50-65

Kohli, A. K \& Jaworski, B. J (1990), Market orientation: The construct, research propositions and Managerial implications. Journal of Marketing, 54 (3), 1-18.

Makadok, R. (2001). Toward a synthesis of the resource-based and dynamic-capability views of rent creation, Strategic Management Journal, 22(5), 387-401

Maklan, S., Knox, S. and Ryals, L. (2005), Building the Business Case for CRM Investments. Long-Range Planning, 38(4), 3893-410

Morah, E. I. M; Wilson, J and Tzempelikos, N (2015), Moderation Effects on the Market Orientation-Performance Connubial Relationship: A Developing World Perspective. Journal of Strategic Marketing, 6(2); 25-45.

Narver, J.C \& Slater S.F (1990), The Effect of Market Orientation on Business Profitability. Journal of Marketing, 54 (October), 20-35.

Njeru,W. G and Kibera, F. N (2016) Marketing Practices, Market Orientation and Performance of Tour Firms in Kenya: A Mediated Approach. DBA Africa Management Review, 6(4): 33-49

O'Cass, A., \& Viet Ngo, L. (2007), Market orientation versus innovative culture: Two routes to superior brand performance. European Journal of Marketing, 41(7/8), 868-887

Ogbonna, B. U and Ogwo, E. O (2013), Market Orientation and Corporate Performance of Insurance Firms in Nigeria. International Journal of Marketing Studies, 5(3): 104 -119

Olanipekun, A. O; Aje, I. O and Abiola-Falemu, J. O (2013), Effects of Organisational Culture on the Performance of Quantity Surveying Firms in Nigeria. International Journal of Humanities and Social Science, 3(5); 206-215

PinhoE. R.,, Rodrigues J. K., \& Dibb H., (2017), Marketing implementation: The implications of marketing paradigm weakness for the strategy execution process. Journal of the Academy of MarketingScience, 26 (3), 222-236

Piercy, N. F;Harris L. C., Lane N (2017), Market Orientation and Retail Operatives' Expectations. Journal of Business Research, 55, 261-273

Shehu, A. M and Mahmood, R (2014) The Relationship between Market Orientation and Business Performance of Nigerian SMEs: The Role of Organizational Culture. International Journal of Business and Social Science, $5(9) ; 159-173$

Zayed, A and Alawad, N (2017) The relationship between Market, Learning Orientation, Innovation and Business Performance of Egyptian SME'S. International Conference on Business \& Entrepreneurship, Supply Chain Management \& Information Systems, Alexandria, Egypt, held May $5^{\text {th }}, 2017$. 